\title{
ANALISIS PROGRAM KEBUGARAN JASMANI PADA PUSAT-PUSAT KEBUGARAN JASMANI DI YOGYAKARTA
}

\section{Oleh: Suharjana \\ Dosen Jurusan Pendidikan Kesehatan dan Rekreasi FIK UNY}

\begin{abstract}
Abstrak
Tujuan penelitian ini adalah: (1) untuk mengetahui cara evaluasi kebugaran dan kesehatan awal bagi setiap member yang akan berlatih di pusat kebugaran, (2) untuk mengetahui program latihan yang akan digunakan untuk mencapai tujuan peserta fitness, (3) untuk mengetahui cara pemantauan program latihan yang telah disusun oleh instruktur.

Penelitian ini adalah penelitian deskriptif. Metode yang digunakan dalam penelitian ini menggunakan metode survei. Populasi dalam penelitian ini adalah member pria atau wanita di fitness center yang ada di Yogyakarta, yang meliputi fitness yang berlokasi di Hotel, ataupun di GOR. Sampel yang digunakan dalam penelitian ini adalah member pria atau wanita di fitness center di Yogyakarta yang berjumlah 30 orang dari 5 fitness center. Teknik sampling yang digunakan dalam penelitin ini adalah insidental sampling. Instrumen dalam penelitian adalah berupa panduan wawancara. Teknik pengumpulan data dengan wawancara langsung kepada member. Analisis data yang digunakan adalah statistik deskriptif kuantitatif dan selanjutnya dilakukan pemaknaan sebagai pembahasan atas permasalahan yang diajukan dengan mengacu pada kaidah-kaidah keilmuan dan teori yang ada.

Hasil penelitian menunjukkan bahwa sebagian besar peserta latihan di fitnes centre adalah para mahasiswa, dengan tujuan untuk membentuk tubuh agar tampil atletis. Program latihan dan proses latihan dibuat dan diawasi oleh instruktur, namun secara umum hasil latihan tidak dilakukan pengukuran sebagai bahan evaluasi, dan evaluasi hanya dilakukan secara kualitatif
\end{abstract}

Kata Kunci: member fitness centre, evaluasi kesehatan

Dalam rangka meningkatkan kualitas kesehatan manusia, olahraga merupakan faktor sangat penting, karena dengan berolahraga manusia akan menjadi sehat. Kesehatan merupakan unsur utama dari kualitas sumber daya manusia. Bapak kedokteran, Hypocrates pernah mengatakan dengan kalimat mutiara yang telah menyebar di masyaakat luas selama lebih dari 2.400 tahun lamanya, yaitu: sinar matahari, udara, air, dan olahraga merupakan sumber kehidupan dan kesehatan. Di sebuah puncak gunung di Yunani, sejak Olympiade Kuno 
telah terukir kata-kata: "Anda ingin menjadi sehat? Anda berlarilah! Anda ingin pintar? Berlarilah! Anda ingin jadi cantik? Berlarilah!” Artinya, bahwa dengan berolahraga orang akan menjadi sehat, menjadi pintar, dan menjadi indah tubuhnya.

Di masyarakat terdapat banyak arena atau tempat olahraga yang dapat digunakan untuk meningkatkan kebugaran jasmani, seperti di lapangan terbuka, atau di gedung olahraga. Di Yogayakarta pada saat ini telah banyak dijumpai pusat-pusat kebugaran (fitness centre) yang dapat menampung orang-orang yang berniat berolahraga. Fitness centre sebagai tempat olahraga mempunyai banyak keunggulan dibanding dengan tempat olahraga yang lain, seperti ada instruktur yang mengawasi latihan, dapat dilakukan secara individu, dan dapat dilakukan kapan saja tidak mengenal waktu. Aktivitas di fitness centre dapat dilakukan pada pagi hari sebelum melakukan pekerjaan atau sore dan malam setelah melakukan pekerjaan. Selain itu, program latihan dapat dipantau dengan mudah. Aktivitas olahraga yang dilakukan di dalam ruang fitness juga lebih diminati banyak orang karena terhindar dari panas matahari atau air hujan.

Olahraga di fitness centre adalah latihan menggunakan beban atau biasa disebut weight training ataupun dengan peralatan lain seperti treadmill, sepeda statis, dan senam. Banyak tujuan yang dapat dicapai dengan olahraga ini, seperti mengembangkan kebugaran aerobik, menguatkan otot, menurunkan berat badan, membentuk tubuh, dan pembesaran otot, bahkan untuk rehabilitasi penyakit dan cedera. Berlatih di finess centre atau pusat-pusat kebugaran akan memudahkan dalam mencapai tujuan tersebut, karena tempat tersebut menyediakan berbagai macam alat sehingga variasi latihan dapat dilakukan dengan mudah. Di Yogyakarta, sebagai kota besar hingga saat ini telah banyak berdiri usaha tempat kebugaran atau fitness centre yang dilakukan oleh para pengusaha industri olahraga.

Terbatasnya instruktur yang memiliki pendidikan sarjana olahraga dengan kompetensi pengelolaan fitness terkadang membuat program-program yang ditawarkan di fitness centre tidak bisa berjalan sesuai kaidah-kaidah latihan yang benar, seperti sistem evalusi program, cara pembebanan, dan cara pemantauan program. Bagi fitness centre yang memiliki konsultan fitness atau instruktur yang memiliki kompetensi yang memadai tentu tujuan yang akan dicapai oleh member akan dapat dijalankan dengan benar. Hingga saat ini belum diketahui secara pasti, apakah program yang ditawarkan pada pusat-puast kebugaran 
jasmani dapat berjalan dengan baik. Beberapa mahasiswa IKORA FIK UNY yang mengikuti PKL di pusat-pusat kebugaran menyatakan bahwa tidak semua program yang ditawarkan bisa berjalan dengan baik. Oleh karena itu untuk mengetahui pola pencapaian tujuan peserta fitness di pusat-pusat kebugaran jasmani perlu dilakukan analisis program kebugaran jasmani melalui kajian penelitian. Berdasarkan batasan masalah di atas rumusan masalah dalam penelitian ini adalah: (1) Apakah ada evaluasi kebugaran dan kesehatan awal bagi setiap member yang akan berlatih di pusat kebugaran? (2) Apakah tujuan yang akan dicapai oleh peserta fitness dibuatkan program latihan oleh instruktur dengan benar? (3) Apakah program latihan yang disusun oleh instruktur dilakukan pemantauan dengan baik oleh instruktur?

\section{KAJIAN TEORETIK}

\section{A. Kajian Pustaka}

Pusat kebugaran adalah tempat olahraga dalam ruangan yang menawarkan berbagai program latihan kebugaran dengan fasilitas dan peralatan yang modern untuk tujuan meraih kesehatan dan prestasi. Pusat kebugaran berasal dari bahasa Inggris fitness center yaitu dari kata fitness dan centre yang dalam konteks bahasa Indonesia fitness artinya kebugaran dan centre artinya pusat, dengan demikian fitness center adalah pusat kebugaran. Giriwijoyo (2007: 35) menyatakan bahwa pusat kebugaran adalah suatu kegiatan dalam ruangan dengan menawarkan kegiatan olahraga dengan menggunakan alat, atau tanpa menggunakan alat-alat yang mahal dan canggih, yang di antaranya bertujuan kesehatan atau prestasi. Dalam perkembangan selanjutnya, fitness center menjadi salah satu usaha yang prospektif dan banyak diminati dalam dunia usaha. Pusat kebugaran bukan saja bertujuan untuk memasyarakatkan olahraga semata, tetapi lebih dari itu ialah untuk mendapatkan keuntungan finansial bagi pemiliknya. Ada dua sasaran yang ingin dicapai dari pengembangan pusat kebugaran yaitu untuk memajukan olahraga masyarakat (kebugaran) dan untuk mencarai keuntungan ekonomi bagi pelaku usaha (laba pengusaha).

Dilihat dari sisi pencapaian kebugaran yang diperhatikan oleh pusat kebugaran adalah pelayanan terhadap member (peserta olahraga di pusat kebugaran). Satu hal 
yang penting adalah pencapaian tujuan olahraga dari para member. Berdasarkan aspek tersebut, pusat kebugaran akan membuat standar operasional prosedur (SOP) bagi para member jika ingin berlatih olahraga pada salah satu pusat kebugaran. Menurut Howley dan Franks (1992) paling tidak ada tiga langkah yang biasa diterapkan dalam pusat kebugaran, yaitu: (1) evaluasi kesehatan awal, (2) penyusunan dan pelaksanaan program, dan (3) evaluasi program.

1. Evaluasi Kesehatan Awal

Evaluasi status kesehatan merupakan suatu cara dalam menentukan tingkat kesehatan sehingga dapat mempermudah penglasifikasian dalam melakukan latihan aktivitas fisik. Evaluasi status kesehatan dapat dijadikan acuan dalam kriteria pengelompokan untuk peserta latihan kebugaran. Menurut Howley dan Franks (1992) berbagai cara dapat dilakukan untuk mengukur status kesehatan seseorang di antaranya yaitu dengan menggunakan PAR-Q (The physical activity readiness questionnaire) yang sangat cocok digunakan untuk penyaringan pada latihan berintensitas rendah.

2. Penyususnan Program Kebugaran

Program latihan adalah suatu program, perencanaan latihan yang memiliki tujuan yang kongkrit disusun secara sistematis yang dijadikan acuan untuk berlatih dengan penuh semangat untuk mencapai tujuan tertentu. Dalam program latihan sangat dibutuhkan ketelitian dalam menyusun programnya karena kesalahan sedikit saja dapat berdampak buruk bagi member.

Secara umum yang dimaksud kebugaran adalah kebugaran fisik (physical fitness), yaitu kemampuan seseorang untuk dapat melakukan kerja sehari-hari secara efisien tanpa menimbulkan kelelahan yang berlebihan sehingga masih dapat menikmati waktu luangnya. Seseorang yang merasa sehat belum tentu bugar sebab untuk dapat mengerjakan tugas sehari-hari seseorang tidak hanya dituntut bebas dari penyakit saja, tetapi juga dituntut memiliki kebugaran. Menurut Nani (2006: 1) kebugaran dikelompokkan menjadi dua yaitu: (1) kelompok yang berhubungan dengan kesehatan (health related physical fitness) yang terdiri atas komposisi tubuh, kelenturan, kekuatan otot, daya tahan jantung paru, dan daya tahan otot (2) 
kelompok yang berhubungan dengan keterampilan (skill related physical fitness) yang terdiri atas kekuatan, kelincahan, koordinasi, kecepatan, waktu reaksi, daya tahan otot, dan keseimbangan. Pada pusat-pusat kebugaran para member berlatih kebanyakan untuk tujuan perbaikan kebugaran yang berkaitan dengan kesehatan. Komponen-komponen tersebut adalah sebagai berikut: (a) daya tahan jantung paru, (b) kekuatan otot, (c) daya tahan otot, (d) komposisi tubuh dan (e) kelenturan atau fleksibilitas tubuh.

\section{Evaluasi Program}

Pada prinsipnya olahraga adalah pemberian tekanan pada fisik manusia yang dilakukan secara teratur, sistematis, berkesinambungan sedemikian rupa sehingga dapat memperbaiki atau meningkatkan kemampuan tubuh dalam melakukan pekerjaan (Nossek, 1982: 20). Ditinjau dari dimensi biologik, olahraga akan berpengaruh terhadap peningkatan fungsi organ tubuh seperti kerja sistem saraf, jantung, pembuluh darah, alat-alat pernapasan maupun sistem hormonal. Oleh karena itu agar latihan dapat memenuhi sasaran yang diinginkan hendaknya program latihan selalu dilakukan evaluasi dengan cara periodik.

\section{B. Penelitian yang Relevan}

Penelitian yang dilakukan oleh Choirudin (2012) dengan judul Analisis Strategi Pemasaran Dalam Meningkatkan Partisipan Masyarakat Pada Fitness Centre di Yogyakarta, menyimpulkan bahwa keseluruhan strategi pemasaran yang telah dilakukan dan diterapkan oleh fitness centre yang ada di Yogyakarta sudah baik. Hal ini dibuktikan dengan banyaknya jumlah partisipan masyarakat yang berolahraga di fitness centre tersebut, jumlah partisipan masyarakat yang menjadi member terus bertambah dari waktu ke waktu, partisipan masyarakat yang telah menjadi member tidak banyak yang drop out (keluar dari keanggotaan), memiliki omset antara Rp 15.000.000,00 sampai dengan Rp 65.000.000,00, serta dapat membuka anak cabang baru. Selama ini strategi pemasaran yang telah digunakan oleh manajemen fitness centre yang ada di Yogyakarta dalam meningkatkan jumlah partisipan masyarakat adalah dengan meningkatkan kualitas jasa yang berupa program-program latihan maupun senam, 
menyediakan sarana dan prasarana serta fasilitas yang memadai, nyaman dan aman bagi para member, serta meningkatkan kualitas pelayanan kepada member.

Penelitin yang dilakukan oleh Gilang (2010) dengan judul Profil Kebugaran Awal Member Baru Pria Usia 20-25 Fitness Center Gedung Olahraga Fakultas Ilmu Keolahragaan Universitas Negeri Yogyakarta terhadap 20 orang members baru di Fitness Center GOR FIK UNY diperoleh hasil: daya tahan jantung paru $55 \%$ di kategori very poor (sangat buruk), kelentukan $55 \%$ di kategori kurang, kekuatan otot $45 \%$ di kategori sangat kurang, dan lemak $35 \%$ di kategori normal. Berdasarkan hasil penelitian diperoleh kesimpulan sebagai berikut: profil kebugaran member pria fitness center GOR FIK UNY Yogyakarta dari tes daya tahan jantung paru masuk dalam kategori very poor (sangat buruk), tes kelentukan masuk dalam kategori kurang, tes kekuatan otot masuk dalam kategori sangat kurang, tes lemak masuk dalam kategori normal. Berdasarkan kesimpulan di atas, program latihan yang lebih efisien adalah latihan physical fitness, kekuatan, body shaping, weight lost, dan latihan fleksibilitas. Analisis profil kebugaran tersebut lebih memudahkan seorang instruktur dalam memberikan program latihan yang tepat.

\section{METODE PENELITIAN}

\section{A. Desain Penelitian}

Penelitian ini adalah penelitian deskriptif, artinya dalam penelitian ini hanya ingin menggambarkan situasi yang saat ini sedang berlangsung. Metode yang digunakan dalam penelitian ini menggunakan metode survey. Penelitian survey menurut Nazir (2005: 56) adalah penelitian yang dilakukan untuk memperoleh fakta dari gejala yang ada dan mencari keterangan secara faktual tentang suatu fenomena.

\section{B. Definisi Operasional Variabel Penelitian}

Pengertian program kebugaran jasmani di pusat-pusat kebugaran adalah program kebugaran yang ditawarkan oleh pusat-pusat kebugaran jasmani yang terdiri dari kebugaran paru jantung, kekuatan otot, pengencangan otot, pembesaran otot dan penurunan berat badan yang dilakukan melalui latihan baik menggunakan weigh training atau yang lain. 


\section{Populasi dan Sampel Penelitian}

Menurut Sugiyono (2006: 89) populasi adalah wilayah generalisasi yang terdiri atas objek atau subjek yang mempunyai kualitas dan karakteristik tertentu yang ditetapkan oleh peneliti untuk dipelajari dan kemudian ditarik kesimpulannya. Sampel adalah sebagian dari wakil populasi yang diteliti (Suharsimi Arikunto, 2002: 117). Populasi dalam penelitian ini adalah member pria atau wanita di fitness centre yang ada di Yogyakarta, yang meliputi fitness yang berlokasi di Hotel, dan di GOR. Sampel yang digunakan dalam penelitian ini adalah member pria atau wanita di fitness centre di Yogyakarta yang berjumlah 40 orang. Teknik sampling yang digunakan dalam penelitin ini adala insidental sampling.

\section{Instrumen Penelitian dan Teknik Pengumpulan Data}

Instrumen penelitian adalah alat bantu yang dipilih dan digunakan oleh peneliti dalam kegiatannya mengumpulkan data agar kegiatan tersebut menjadi sistematis dan dipermudah olehnya (Suharsimi Arikunto, 2002: 135). Instrumen dalam penelitian adalah berupa panduan wawancara. Teknik pengumpulan data dengan wawancara langsung kepada member. Untuk mencari validitas instrumen dilakukan melalui seminar instrumen dan model triangulasi.

\section{E. Analisis Data}

Analisis data yang digunakan adalah statistik deskriptif kuantitatif dan selanjutnya dapat dilakukan pemaknaan sebagai pembahasan atas permasalahan yang diajukan dengan mengacu pada kaidah-kaidah keilmuan dan teori yang ada.

\section{HASIL PENELITIAN DAN PEMBAHASAN}

Penelitian ini dimaksudkan untuk mengetahui apakah member fitness sebelum berlatih terlebih dahulu menjalani prosedur tes kesehatan dan kebugaran. Disamping itu, apakah selama berlatih program yang jalankan telah berdasarkan program yang benar. Selama proses berlatih ada prosedur evaluasi. Untuk itu pada bagian akan disajikan hasil penelitian sekaligus dilakukan pembahasan.

\section{A. Karakteristik Sampel}

Sampel penelitian ini mempunyai karakteristik sebagai berikut: 
1. Jumlah dan Tempat Pengambilan Data.

Dalam penelitian ini tempat penelitian diklasifikasi pada dua tempat pusat kebugaran, yaitu fitness centre di hotel dan fitness centre di GOR (Gedung Olahraga). Yang dimaksud GOR adalah gedung olahraga yang juga mengelola fasilitas olahraga lain di luar fitness, dan gedung olahraga yang hanya mengelola fitness centre saja. Fitness centre di hotel biasanya manajemennya bergabung dengan manajemen hotel. Sedangkan fitness centre di GOR biasanya manajemen milik perorangan atau sekelompok orang. Dalam penelitian ini data diperoleh dari 5 fitness centre yang berada di hotel di DIY, dan 7 fitness centre yang berada di GOR di Kota Yogyakarta dan Kabupaten Sleman. Dengan demikian ada 12 fitness centre yang digunakan sebagai pusat pengambilan data dalam penelitian ini. Dari 12 fitness centre tersebut 19 orang berasal dari fitness centre hotel dan 21 orang dari fitness centre GOR. Jumlah keseluruhan sampel ada 40 orang yang terdiri atas 33 laki-laki dan 7 orang perempuan.

2. Usia, Pendidikan, dan Pekerjaan Sampel

Jika dilihat dari usia member yang tersebar dalam 12 fitness centre tersebut dapat dijelaskan bahwa member (sampel) yang berusia kurang dari 26 tahun ada 20 orang, yang berumur 26 sampai 30 tahun ada 7 orang, yang berumur lebih dari 30 tahun ada 6 orang. Meskipun demikian, ada 7 orang yang tidak mau menyebutkan usianya. Sementara itu dari sisi pendidikan para member yang masih berpendidikan SMA ada 25 orang, pendidikan setara S1 ada 7 oang, sementara ada 8 orang merahasiakan pendidikannya. Dari aspek pekerjaan sampel ada 19 orang berstatus mahasiswa (kuliah), karyawan/pegawai ada 5 orang, ibu rumah tangga ada 3 orang, dan ada 7 orang tidak mau menyebutkan pekerjaannya.

Berdasarkan karakteristik sampel ada beberapa yang perlu dikaji lebih mendalam yaitu jenis kelamin member kecenderungannya adalah laki-laki. Hal ini menunjukkan bahwa orang laki-laki lebih memperhatikan gaya hidup sehat, penampilan atau performa. Jika dilihat dari usia para member sebagian besar adalah usia di bawah 26 tahun yang sekaligus sebagian besar adalah kelompok mahasiswa. Data ini memberikan makna bahwa para mahasiswa lebih ingin menjaga penampilan 
daripada orang dewasa. Kesibukan orang dewasa menjadi alasan mengapa tidak terbiasa dengan olahraga, sedangkan para mahasiswa lebih memperhatikan kesehatan dan penampilan karena usia mahasiswa membutuhkan tubuh yang ideal dan berpenampilan yang baik.

\section{B. Pengukuran Kesehatan dan Kebugaran Awal}

Konsep dasar latihan menyatakan bahwa sebelum berolahraga seseorang dianjurkan untuk menjalani serangkain tes kesehatan dan pengukuran kebugaran dengan maksud untuk megetahui kondisi fisik dan kesehatan awal (sebelum latihan). Penelitian menemukan bahwa semua member (0 orang) yang masuk di fitness centre tidak dilakukan pengecekan kesehatan fisiknya. Hal ini disebabkan sebagian besar fitness centre tidak memiliki dokter. Jika member ada keluhan tentang kesehatan dianjurkan secara pribadi berkonsultasi dengan dokter di rumah sakit.

Pengukuran antropometri tinggi badan dan berat badan sebagian besar member yaitu 36 orang melakukan pengukuran sebelum memulai program latihan. Alat untuk mengukur berat badan yang berupa timbangan harganya relatif murah dan pelaksanaan pengukurannya sangat mudah, bahkan member dapat melakukan pengukuran sendiri, di sisi lain hasil dari pengukuran itu langsung dapat diketahui hasilnya. Alasan inilah yang menyebabkan pengukuran berat badan ini menjadi pilihan penyelenggara fitness centre. Dengan diketahui berat badan seseorang, dapat diketahui apakah orang tersebut kelebihan atau kekurangan berat badan, sehingga dapat mempermudah pilihan program.

Dari 40 member yang digunakan sebagai sampel penelitian ada 13 orang yang melakukan pengukuran antropometri lain sebelum program latihan dimulai, yaitu berupa pengukuran lingkar tubuh dan pengukuran tebal lemak di bawah kulit. Pengukuran antropomentri ini khususnya pada pengukuran lingkar lengan, lingkar dada, dan lingkar paha. Kajian lebih lanjut menunjukkan bahwa pengukuran antropometri ini lebih ditujukan bagi member yang bertujuan untuk menurunkan atau menaikkan berat badan. Sementara itu untuk pengukuran tebal lemak di bawah kulit ada 7 orang. Hasil ini menunjukkan bahwa pengukuran tebal lipatan kulit kurang menjadi perhatian dari fitness centre. Penyelidikan lebih lanjut menunjukkan bahwa 
pengukuran tebal lipatan kulit biasanya ditujukan bagi member yang bertujuan menurunkan berat badan. Data triangulasi menyatakan bahwa sebenarnya setiap member yang akan memulai program latihan selalu dilakukan pengukuran tebal lemak pada lipatan kulit, akan tetapi tidak semua member bersedia dilakukan pengukuran ini terutama bagi members yang merasa lemaknya tidak berlebihan.

Dari sisi kebugaran jasmani, tes awal yang dijalankan berupa tes aerobik. Tes ini biasanya menggunakan treadmill atau sepeda statis. Member yang melakukan tes aerobik sangat sedikit yaitu hanya lima orang. Kajian lebih lanjut mengapa tes aerobik kurang diperhatikan ternyata sebagian besar fitness centre tidak memiliki alat tes aerobik yang berupa treadmill, sementara tes lapangan seperti misalnya lari 12 menit kurang disukai oleh member. Kondisi ini sebenarnya sangat memrihatinkan karena itu disarankan agar setiap fitness centre harus memiliki alat tes kebugaran aerobik. Di sisi lain data penelitian menemukan ada empat orang yang tidak melakukan tes awal dalam bentuk apa pun. Hal ini disebabkan oleh keyakinan member bahwa dengan latihan otomatis akan memperbaiki kondisi fisik sesuai tujuan yang diinginkan.

\section{Penyusunan Program Latihan}

1. Tujuan latihan

Member datang ke fitness centre tentu mempunyai tujuan terutama berkaitan dengan pemeliharaan kondisi fisik dan kesehatan. Hasil penelitian menunjukkan bahwa tujuan latihan paling banyak yaitu lima belas orang adalah untuk hipertrofi otot atau body bulding atau sering disebut program pembesaran otot. Hal ini identik dengan karateristik member yang sebagian besar adalah mahasiswa. Mahasiswa masuk dalam puncak pertumbuhan terkadang ototnya masih lembek sehingga penampilannya kurang gagah, dan berat badannya terkadang di bawah normal. Para mahasiswa inilah yang kebanyakan bertujuan ingin membesarkan otot. Di sisi lain ada yang bertujuan untuk pengencangan otot atau body shaping, yaitu ada sepuluh orang dan yang bertujuan menurunkan berat badan ada sembilan orang. Para member yang ototnya kendor dan berlemak biasanya menginginkan program dengan tujuan mengencangkan otot. Sebelum mengikuti program pengencangan otot biasanya menjalankan latihan untuk menurunkan berat badan atau latihan 
dengan program kombinasi penurunan berat badan (fat loss) dengan pengencangan otot. Sementara ada tiga orang yang bertujuan untuk mencapai performa, baik performa dalam olahraga sebagai atlet maupun performa dalam pekerjaanya yang menuntut kemampuan fisik tertentu. Dari sekian member ada yang menginginkan tujuan ganda karena itu dari aspek tujuan latihan ada dua belas orang yang menyatakan berkeinginan memperbaiki kesehatannya.

Dari sekian tujuan latihan ternyata sebagian besar tujuan latihan adalah untuk pembesaran otot. Hal ini sejalan dengan karakteristik member yang kebanyakan mahasiswa. Mahasiswa yang tidak suka berolahraga sementara intensitas belajar dan kuliahnya tinggi cenderung badannya kerempeng (kecil). Alasan inilah yang membuat mahasiswa ingin membesarkan ototnya agar tubuh tampak tegap dan bugar.

2. Pembuatan Program latihan

Dari 40 member ternyata ada 29 orang yang program latihannya dibuatkan oleh instruktur dan 11 orang dibuat sendiri. Pengetahuan member akan prinsip latihan, konsep latihan dan cara menggunakan peralatan latihan membuat para member kurang memahami cara berlatih di fitness centre dengan benar. Alasan inilah yang membuat para member menggantungkan instruktur untuk membuatkan dan mengawasi program latihan sesuai tujuan. Sementara sebelas orang yang tidak memerlukan program latihan dari instruktur beralasan yang penting dapat melakukan cara menggunakan alat latihan dan ada insruktur yang mengawasi mudah-mudahan latihan juga ada manfaatnya. Data triangulasi menyatakan semua member yang masuk fitness centre akan dibuatkan program latihan sesuai tujuan yang diinginkan, namun ada beberapa member yang ingin mengunakan program yang dibuat sendiri. Dalam hal ini instruktur dimintai bantuan untuk menjelaskan cara penggunaan alat dan mengawasi latihan. 
3. Lama Latihan

Hasil penelitian menunjukkan bahwa lama latihan kurang dari 3 bulan ada 10 orang, berlatih antara $4-6$ bulan ada 18 orang, berlatih antara $7-9$ bulan ada 8 orang, berlatih lebih 10 bulan ada 5 orang. Lama latihan member paling banyak adalah 4-6 bulan. Teori latihan menyatakan bahwa hasil latihan akan tampak ada perubahan setelah lama latihan 2 bulan atau lebih dan perubahan latihan akan tampak nyata setelah periode 4-6 bulan. Member biasanya akan mulai bosan dan merasa puas setelah latihan merasa berhasil. Setelah latihan dapat mencapai tujuan kebanyakan member mengurangi frekuensi latihan atau bahkan berhenti dari latihan. Para member akan kembali ke fitness centre setelah merasa kebugarannya kembali menurun.

\section{Evaluasi Program}

1. Kesesuaiaan Program dengan Tujuan

Program latihan yang baik adalah program yang sesuai dengan tujuan latihan. Jika latihan bertujuan untuk mengurangi berat badan, program yang cocok adalah aktivitas aerobik dengan intensitas 65-75 \% dari denyut jantung maksimum. Sementara itu, jika latihan bertujuan untuk pengencangan otot, program weight training dengan beban 15 RM merupakan cara yang ideal. Hasil penelitian menunjukkan bahwa 37 orang menyatakan program yang diikuti telah sesuai dengan tujuan dan hanya 3 orang yang merasa gagal. Hasil ini menggambarkan bahwa fitness centre telah memberikan pelayanan yang baik.

2. Implementasi Evaluasi Program

Untuk mengetahui efektivitas sebuah program dapat dilakukan dengan cara melakukan evaluasi. Program tanpa ada evaluasi maka tidak dapat diketahui kemajuan maupun kendala-kendala yang menyertai latihan. Hasil penelitian menyatakan bahwa 32 orang tidak pernah dilakukan evaluasi oleh pembuat program, dan hanya ada 8 orang yang merasa dievaluasi. Kondisi ini kontradiktif dengan temuan yang menunjukkan bahwa sebagian besar program latihan sudah sesuai dengan tujuan latihan. Hal ini disebabkan pada pemahaman member bahwa kesesuaian program dengan tujuan latihan lebih dimaknai oleh perubahan fisik 
(secara kualitatif) yang ada pada member tanpa didukung data yang objektif. Apapun alasanya evaluasi program harus dilakukan secara periodik setiap bulan atau tiga bulan sekali untuk mengetahui perkembangan latihan. Data triangulasi menyatakan bahwa evaluasi menyeluruh memang tidak ada, tetapi evaluasi terhadap pembebanan latihan selalu ada pemantauan sehingga member setiap latihan akan menggunakan beban yang sesuai. 


\section{KESIMPULAN}

Berdasarkan hasil penelitian dan kajian melalui pembahasan, penelitian ini menyimpulkan sebagian berikut:

1. Sebagian besar peserta latihan di fitnes centre adalah para mahasiswa, dengan tujuan untuk membentuk tubuh agar tampil atletis.

2. Sebelum member berlatih ada pengukuran awal terutama pengukurn berat badan, tetapi untuk tes kesehatan hampir semua penyedia fitness centre tidak melakukannya.

3. Untuk penyusunan program latihan hampir semua member dibuatkan oleh instruktur, begitu juga dengan proses latihan semua member dibawah pengawasan instruktur

4. Secara umum hasil latihan tidak dilakukan evaluasi secara terjadwal, tetapi pada proses latihan selalau diadakan pemantauan oleh instruktur. Keberhasilan latihan dimaknai secara kualitatif oleh para member. 


\section{DAFTAR PUSTAKA}

Choirudin. (2012). Strategi Pemasaran Pusat-Pusat Kebugaran di Yogyakarta. Tesis, Yogyakarta PPs UNY.

Gilang Anggarkusuma. (2010). Profil Kebugaran Awal Member Baru Pria Usia 20-25 Fitness Center Gedung Olahraga Fakultas Ilmu Keolahragaan Universitas Negeri Yogyakarta. Skripsi. Yogyakarta. FIK UNY.

Giriwijoyo, Santoso. (2007). Ilmu Faal Olahraga. Bandung. Fakultas Pendidikan Olahraga dan Kesehatan UPI.

Howley, E.T., dan Franks, B.D. (1992). Health Fitness, Instructor's Handbook. South Australia: Kinetics Publisher.Inc.

Nossek, J. (1982). General Theory of Training. Lagos: National Institut for Sport, Pan African Press Ltd.

Nasir, M. (2003). Metode Penelitian. Jakarta: Ghalia Indonesia.

Nani Cahyani Sudarsono. (2008). Kuliah Pengantar pada Kelas Foundation - Mata Kuliah Fitness and Art Tingkat Persiapan STEKPI. Modul On Line. Diunduh 8 Maret 2008.

Suharsimi Arikunto. (2002). Manajemen Penelitian. Jakarta: PT Rineka Cipta.

Sugiyono. (2006). Metode Penelitian Kuantitatif, Kualitatif dan $R \& D$. Bandung: Alfabeta. 